\title{
Effect of Heat-treatment Atmosphere on Photoluminescence of Eu-doped Li-Al-O System
}

\author{
Jeong Seog Kim*, Chae Il Cheon**, and Ki-Woong Chae**,† \\ *Department of Display Engineering, Hoseo University, Asan, Chungnam 336-795, Korea \\ **Department of Materials Science and Engineering, Hoseo University, Asan, Chungnam 336-795, Korea \\ (Received Septembe 11, 2013; Revised November 1, December 20, 2013; Accepted December 20, 2013)
}

\section{열처리 분위기가 $\mathbf{E u}$ 이온이 첨가된 Li-Al-O계 형광체 특성에 미치는 영향}

\author{
김정석* · 천채일** · 채기웅**,† \\ *호서대학교 디스플레이공학과 \\ **호서대학교 신소재공학과
}

(2013년 9월 11일 접수 ; 2013년 11월 11일, 12월 20일 수정 ; 2013년 12월 20일 채택)

\begin{abstract}
New green phosphor is synthesized by reducing $\mathrm{LiAlO}_{2}: \mathrm{xEu}^{3+}$ phosphors in a low pressure $\mathrm{H}_{2}$ atmosphere. $\mathrm{The}^{\mathrm{LiAlO}} \mathrm{Al}_{2}: \mathrm{xEu}^{3+}$ prepared by a solid state reaction method is reported as red phosphor. The effect of the reduction treatment on the $\mathrm{LiAlO}_{2}: \mathrm{xEu}^{3+}$ on the crystalline phase change and photoluminescence (PL) property are characterized. The reduced phosphor had a broad green light spectrum centered at $524 \mathrm{~nm}$. The PL intensity of the reduced phosphor increased to a maximum at the reduction temperature of $1100^{\circ} \mathrm{C}$. The PL intensity decreased with a further increase in the reduction temperature. The crystalline phase constituting the reduced phosphor varied with the temperature. A new crystalline phase $\mathrm{Li}_{2} \mathrm{Al}_{4} \mathrm{O}_{7}$ was observed at $1100^{\circ} \mathrm{C}$. The origin of the green-light emission is discussed in relation to the crystalline phase change.
\end{abstract}

Key words : Phosphor, Europium, Lithium aluminate, Reduction atmosphere

\section{1. 서 론}

LED 칩의 발광효율 및 형광체 기술의 급속한 발전으 로 $\mathrm{LED}$ 는 다양한 전자디스플레이소자의 부품으로 사용 이 되고 있으며, 에너지 절감 및 친환경 이슈와 관련하여 이들 소자의 산업적 적용은 앞으로도 빠르게 진행될 것 으로 판단된다. 그런데 이들 소자의 성능향상과 수명연장 을 위해서는 우수한 발광효율 및 연색성을 갖는 형광체 조성과 제조 공정의 개발이 필수적이다. 기존 형광체 및 새로운 형광체 개발에 있어서 중요한 역할을 해 온 재료 는 주로 희토류 이온들이다. 특히, $\mathrm{Eu}$ 이온은 다양한 세 라믹스 기지상에 첨가되어 우수한 형광특성을 보여 주고 있다. ${ }^{1,2)}$ 물론, 이러한 희토류 금속이온에 의한 형광 특성 은 모체 (기지재료, 세라믹 재료)의 종류에 따라 크게 영 향을 받는다.

한편, 형광체의 일반적인 제조방법은 고상합성법 ${ }^{3,4)}$, 졸겔법 ${ }^{5,6)}$, 열수방법 ${ }^{7)}$ 및 연소합성법 ${ }^{8,9)}$ 등으로 다양하게 적

\footnotetext{
${ }^{\dagger}$ Corresponding author : Ki-Woong Chae

E-mail : chaekw@hoseo.edu

Tel : +82-41-540-5765 Fax : +82-41-548-3502
}

용되고 있다. 이들 중 고상합성법이 가장 간단하며 손쉽 게 형광물질을 합성할 수 있는 방법으로 알려져 있는데, 합성하는 과정에서 합성온도, 그리고 합성 후 이루어지는 환원 열처리 ${ }^{10)}$ 와 온도 등의 여러 변수들이 형광체의 물 성을 좌우하는 것으로 알려져 있다.

본 연구에서는 적색형광체인 $\mathrm{Eu}$ 이온이 첨가된 $\mathrm{LiAlO}_{2}$ $\left(\mathrm{LiAlO}_{2}: \mathrm{Eu}^{3+}\right)$ 을 이용하여 고상합성법으로 합성하고 새로 운 열처리공정을 도입하여 새로운 녹색 형광체를 제조하 였다. 그리고 형광체의 결정상 변화, 발광특성 변화, 및 발광기구 등을 고찰하였다. 기존에 $\mathrm{Li}_{2} \mathrm{O}-\mathrm{Al}_{2} \mathrm{O}_{3}$ 계를 이용한 형광체는 거의 보고된 바가 없으며, 이제까지 알려진 것으 로는 $\mathrm{LiAlO}_{2}$ 에 $\mathrm{Eu}$ 또는 $\mathrm{Fe}$ 를 첨가한 적색형광체가 보고되 어있다. ${ }^{6,8)} \mathrm{LiAlO}_{2}$ 는 잘 알려져 있지 않은 형광체이나 열적 으로 안정한 결정구조를 가지고 있어 형광체 및 고체 레이 저 모체로서 적합한 물성을 가진 것으로 보고되었다. ${ }^{11,12)}$ 본 연구에서는 진공 환원분위기 열처리를 통해 새로운 녹 색형광체를 제조하는 것을 목적으로 하였다. 기존에 보고 된 형광체 조성인 $\mathrm{LiAlO}_{2}: \mathrm{Eu}^{3+}$ 에 진공환원분위기라는 새 로운 공정을 도입함으로써 $\mathrm{Li}-\mathrm{Al}-\mathrm{O}$ : Eu계에서 새로운 형 광체 물질을 개발할 수 있는 가능성을 제시하였다. 


\section{2. 실험 방법}

본 연구에서 $\mathrm{Eu}$ 이온이 첨가된 $\mathrm{LiAlO}_{2}$ 형광체는 2 단계 를 거쳐 제조하였다. 최종 형광체 조성물은 $\mathrm{LiAlO}_{2}: \mathrm{xEu}$ 로 나타내어진다. 첫 단계로, 출발원료를 $\mathrm{Li}_{2} \mathrm{CO}_{3}, \mathrm{Al}_{2} \mathrm{O}_{3}$ (AKP-50, Sumitomo) 및 $\mathrm{Eu}_{2} \mathrm{O}_{3}(99.9 \%$ STREM Co.)로 하여 $\mathrm{Eu} / \mathrm{Li}$ 의 몰비(x)가 $0.01,0.1,0.2,0.5$ 가 되도록 원료 분말의 조성을 맞추었고, 일반적인 고상합성법으로 합성 하였다. 각각의 조성에 따라 칭량된 분말들은 알코올을 용매로 막자사발을 이용하여 혼합하였다. 이후 건조하고, 고순도의 알루미나 도가니에 넣어 $850^{\circ} \mathrm{C}$ 까지 $10^{\circ} \mathrm{C} / \mathrm{min}$ 의 속도로 승온시켜 공기 중의 분위기에서 5 시간 동안 열처 리하였다. 이후 분쇄하고 $1100^{\circ} \mathrm{C}$ 에서 5 시간 동안 다시 한 번 열처리함으로써 1 단계의 적색형광체를 얻었다.

이렇게 얻어진 $\mathrm{Eu}$ 이온이 첨가된 $\mathrm{LiAlO}_{2}$ 형광체 분말 을 가지고 다시 2단계 열처리공정을 실시하였다. 알루미 나 도가니에 넣어 흑연 발열체의 소결로에서 진공 환원 분위기 처리를 하였다. 환원 분위기는 진공소결로의 내부 를 0.01 torr까지 진공으로 만들고, 이후 고순도 수소 (99.999\%)를 흘려 챔버의 내부압력을 1 torr로 유지하면서 $1000^{\circ} \mathrm{C}, 1100^{\circ} \mathrm{C}$, 그리고 $1200^{\circ} \mathrm{C}$ 의 온도에서 각각 5 시간 동안 열처리를 실시하여 최종형광체를 제조하였다.

각각의 단계에서 얻어진 분말들은 $\mathrm{XRD}$ 로 상분석을 행 하였으며, UV-VIS Fluorescence Spectrometer를 이용하여 PL (Photoluminescence) 특성을 측정하였다. 아울러, 합성 된 분말들의 미세조직을 주사전자현미경 (SEM) 및 $\mathrm{EDX}$ 로 관찰하였다.

\section{3. 결과 및 고찰}

Fig. 1은 $\mathrm{LiAlO}_{2}$ 에 $\mathrm{Eu}$ 이온 $(\mathrm{Eu} / \mathrm{Li}=0.1)$ 을 첨가하여 일반적인 고상합성법으로 $1100^{\circ} \mathrm{C}$ 에서 합성하여 얻은 형 광체 분말의 여기-발광 스펙트럼이다. 여기 스펙트럼 (a) 에서 $200 \sim 500 \mathrm{~nm}$ 에 걸친 광범위한 파장영역에서 흡수가 일어나고 있으며, 최대 여기파장은 $283 \mathrm{~nm}$ 인 것을 알 수 있다. 최대 여기파장인 $283 \mathrm{~nm}$ 를 조사하여 얻은 발광스 펙트럼 (b)로부터 $590 \sim 620 \mathrm{~nm}$ 의 좁은 영역에서 발광 파 장이 관찰되며, 주 발광피크는 $614 \mathrm{~nm}$ 인 것을 알 수 있다. 즉, $\mathrm{Eu}$ 이온이 첨가된 $\mathrm{LiAlO}_{2}$ 형광체는 전형적인 적색 형 광체임을 확인할 수 있다. $\mathrm{Eu}^{+3}$ 이온이 첨가된 $\mathrm{LiAlO}_{2}$ 형 광체는 이미 적색 형광체로 보고된 바 있다. ${ }^{6)}$ 그런데 일 반적인 고상합성법으로는 형광체 합성이 불가능하였고, 졸-겔법이나 연소법을 통한 합성으로 제조된 형광체에서 만 적색발광이 나타나는 것으로 보고되었다. ${ }^{6,8)}$ 연소법에 의한 합성에서는 합성한 이후에 열처리하면 형광특성이 사라지는 것을 보고하였다. ${ }^{8)}$ 이렇게 일반적인 고상합성법 으로 제조된 $\mathrm{LiAlO}_{2}$ 으로부터 적색발광 형광체를 얻을 수

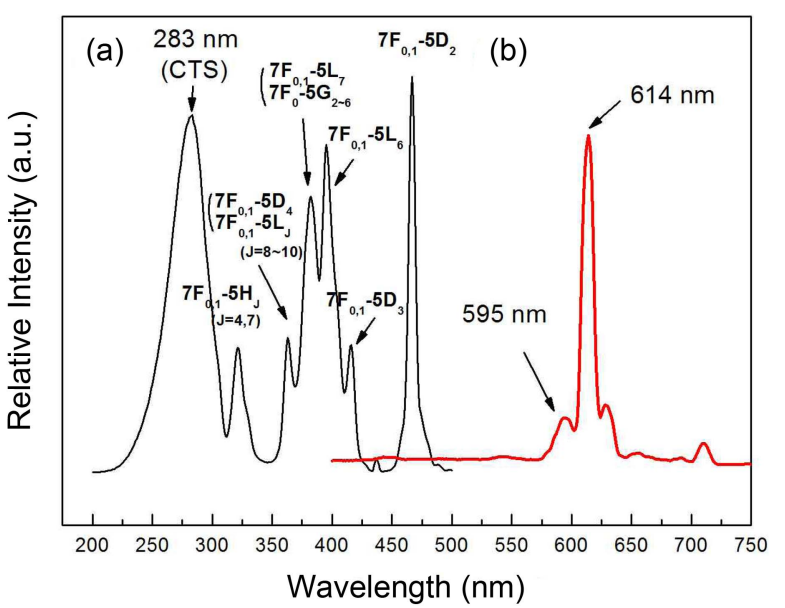

Fig. 1. PL spectrum of Eu-doped $\gamma-\mathrm{LiAlO}_{2}(\mathrm{Eu} / \mathrm{Li}=0.1)$. The samples were annealed at $1100^{\circ} \mathrm{C}$ in air for $5 \mathrm{~h}$ : (a) the excitation spectrum measured while observing the emission line at $614 \mathrm{~nm}$ and (b) the emission spectrum measured under the $283 \mathrm{~nm}$ excitation. (a)

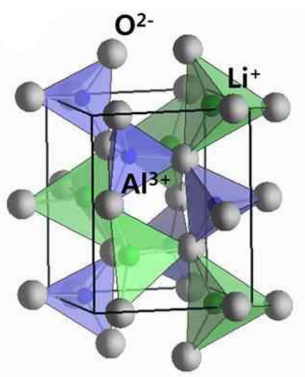

(b)

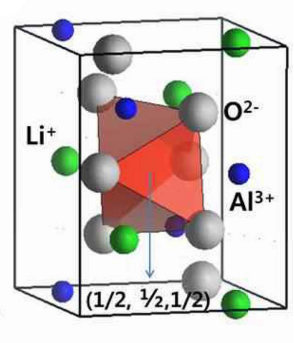

Fig. 2. Crystal structure of (a) the $\gamma-\mathrm{LiAlO}_{2}$ and (b) octahedral interstitial site.

없는 이유로는 첨가되는 $\mathrm{Eu}^{+3}$ 이온의 크기가 모체인 $\mathrm{Li}^{+1}$ 및 $\mathrm{Al}^{+3}$ 이온의 크기와 비교하여 상대적으로 매우 커서 일반적인 고상합성법으로는 치환이 일어나지 못하기 때 문으로 알려져 있다. ${ }^{8)}$ 그러나 본 연구에서는 기존 보고와 는 달리 고상반응법에 의해서도 우수한 적색 발광 특성 을 얻을 수 있었다.

Fig. 2(a)는 $\mathrm{LiAlO}_{2}$ 의 결정구조 (SG P4 $2_{1} 2, a=\mathrm{a}=$ $5.16 \AA, \mathrm{c}=6.26 \AA)$ 를 보여준다. 두 양이온 $\left(\mathrm{Li}^{+1}, \mathrm{Al}^{+3}\right)$ 은 모두 사면체 배위를 형성한다. $\mathrm{Li}^{+1}$ 와 $\mathrm{Al}^{+3}$ 이온이 형 성한 4 면체 배위의 체적 (tetrahedron volume)은 각각 $3.8 \AA^{3}$ 과 $2.77 \AA^{3}$ 이다. 이들 사면체 배위 자리에 있는 $\mathrm{Li}^{+1}$ $(0.73 \AA)$ 및 $\mathrm{Al}^{+3}(0.53 \AA)$ 이온들의 크기는 $\mathrm{Eu}^{3+}$ 이온 $(1.08$ $\AA$ )보다 매우 작기 때문에 $\mathrm{Eu}^{3+}$ 이온은 이 사면체 배위자 리에 치환되기가 어렵다고 판단된다. 반면에 이 단위정의 중심 $(1 / 2,1 / 2,1 / 2)$ 에 존재하는 양이온이 채워져 있지 않 은 6 배위 자리의 체적 (팔면체 부피 $=12.9 \AA^{3}$ )은 매우 크기 때문에 (Fig. 2(b)), $\mathrm{Eu}^{3+}$ 이온이 이 자리 $(1 / 2,1 / 2,1 /$ 2)를 침입형으로 채울 수 있을 것으로 예상된다. 
Fig. 1에서 $\mathrm{LiAlO}_{2}: \mathrm{Eu}^{3+}$ 형광체가 보여주는 적색 형광 특성은 $\mathrm{Eu}^{+3}$ 이온에 의해 나타나는 전형적인 f-f 천이 (transition) 및 charge transfer state (CTS)임을 알 수 있다. 발광스펙트럼 (b)에서 주피크인 $614 \mathrm{~nm}$ 는 ${ }^{5} \mathrm{D}_{0} \rightarrow$ ${ }^{7} \mathrm{~F}_{2}$ 전이 (electric dipole transition)에 의해, 그리고 595 $\mathrm{nm}$ 에서 관찰되는 작은 피크는 ${ }^{5} \mathrm{D}_{0} \rightarrow{ }^{7} \mathrm{~F}_{1}$ 전이 (magnetic dipole transition)에 의해 일어나는 것으로 알려져 있다. ${ }^{1,2)}$ $\mathrm{LiAlO}_{2}: \mathrm{Eu}^{3+}$ 형광체를 공기 중에서 합성할 때 원료로 사 용한 $\mathrm{Eu}_{2} \mathrm{O}_{3}$ 중에서 일부 $\mathrm{Eu}$ 이온은 $\mathrm{LiAlO}_{2}$ 결정격자 내 에 고용 되어 존재하고, 나머지는 고용이 안 되어 $\mathrm{Eu}_{2} \mathrm{O}_{3}$ 로 남아 있게된다. 따라서 Fig. 1에서 적색 발광은 고용 된 $\mathrm{Eu}^{3+}$ 이온과 고용이 되지 않고 남아 있는 $\mathrm{Eu}_{2} \mathrm{O}_{3}$ 로부 터 발생한 것으로 판단된다.

한편, $\mathrm{Eu}^{+3}$ 이온이 $\mathrm{Eu}^{+2}$ 이온으로 환원되는 경우 $5 \mathrm{~d}-4 \mathrm{f}$ 전이에 의해 발광 천이가 나타나는데, 이때 $5 \mathrm{~d}$ 에너지 레 벨이 모체의 결정장 (crystal field)에 의해 영향을 받기 때 문에 녹색에서 파란색에 이르는 광범위한 발광특성이 나 타난다. 본 연구에서도 $\mathrm{Eu}^{+3}$ 이온을 환원시켜 새로운 형 광특성을 구현하기 위해 수소에 의한 환원 및 진공분위 기를 이용하여 열처리를 실시하였다.

Fig. 3은 $\mathrm{LiAlO}_{2}$ 에서 $\mathrm{Eu} / \mathrm{Li}$ 의 몰비를 $0.01,0.1,0.2$ 그 리고 0.5 로 변화시킨 조성을 $1100^{\circ} \mathrm{C}$ 에서 1 단계 가소성하 여 적색형광체를 만들고, 이를 또다시 $1100^{\circ} \mathrm{C}$ 에서 1 torr 의 수소 환원 분위기에서 5 시간 열처리 (2단계 환원 분위 기처리)하여 얻은 형광체 분말의 여기-발광 스펙트럼이다. 여기 스펙트럼 (Fig 3(a))에서는 $250 \sim 480 \mathrm{~nm}$ 의 넓은 영 역에서 완만한 형태의 흡수 파장이 관찰되고 있으며, 이 때 최대 흡수피크는 $396 \mathrm{~nm}$ 인 것을 알 수 있다. (b)는 발 광스펙트럼으로 $524 \mathrm{~nm}$ 에서 가장 큰 피크 값을 보이며, $460 \sim 650 \mathrm{~nm}$ 영역의 넓은 곡선으로 관찰되고 있어 전형 적인 녹색형광체 특성을 보이고 있다. 즉, Fig. 1에서 관 찰되던 적색 형광체 $\mathrm{LiAlO}_{2}$ 가 1 torr 압력의 수소 환원분 위기 열처리에 의해 여기 및 발광스펙트럼이 녹색 형광 체로 변화하였다. 한편, $\mathrm{Eu} / \mathrm{Li}$ 의 몰비에 따라 발광 강도값 이 변화하고 있는데, $\mathrm{Eu}$ 이온의 첨가량이 증가 $(\mathrm{Eu} / \mathrm{Li}=$ 0.2 할수록 강도값이 증가하다가 이후로 감소하고 있다.

$\mathrm{LiAlO}_{2}$ 에 첨가된 $\mathrm{Eu}$ 이온은 환원분위기 처리에 의해 $524 \mathrm{~nm}$ 에서 최대 발광 강도값을 보이는 녹색 형광체로 변 화하였다. Fig. 4는 수소 환원 분위기 처리를 통해 얻어 진 $\mathrm{LiAlO}_{2}$ 형광체를 $254 \mathrm{~nm}$ 및 $365 \mathrm{~nm}$ (사진 오른쪽 아 래)의 여기파장으로 조사하여 눈으로 관찰한 결과이다. Fig. 4의 왼쪽 아래는 동일 시편들을 자연광 아래서 얻은 사진이다. $1100^{\circ} \mathrm{C}$ 에서 1 단계 열처리한 $\mathrm{LiAlO}_{2}(\mathrm{LA}: \mathrm{Eu} /$ $\mathrm{Li}=0.1)$ 는 적색 형광특성을 보이고 있으며, 이후 수소 환원분위기 처리에 의해 녹색형광체로 변화한 것을 확인 할 수 있다. Fig. 1의 여기-발광 스펙트럼에서 예상할 수 있듯이 $\mathrm{LiAlO}_{2}$ 는 적색 형광특성을 보일 때는 $365 \mathrm{~nm}$ 에
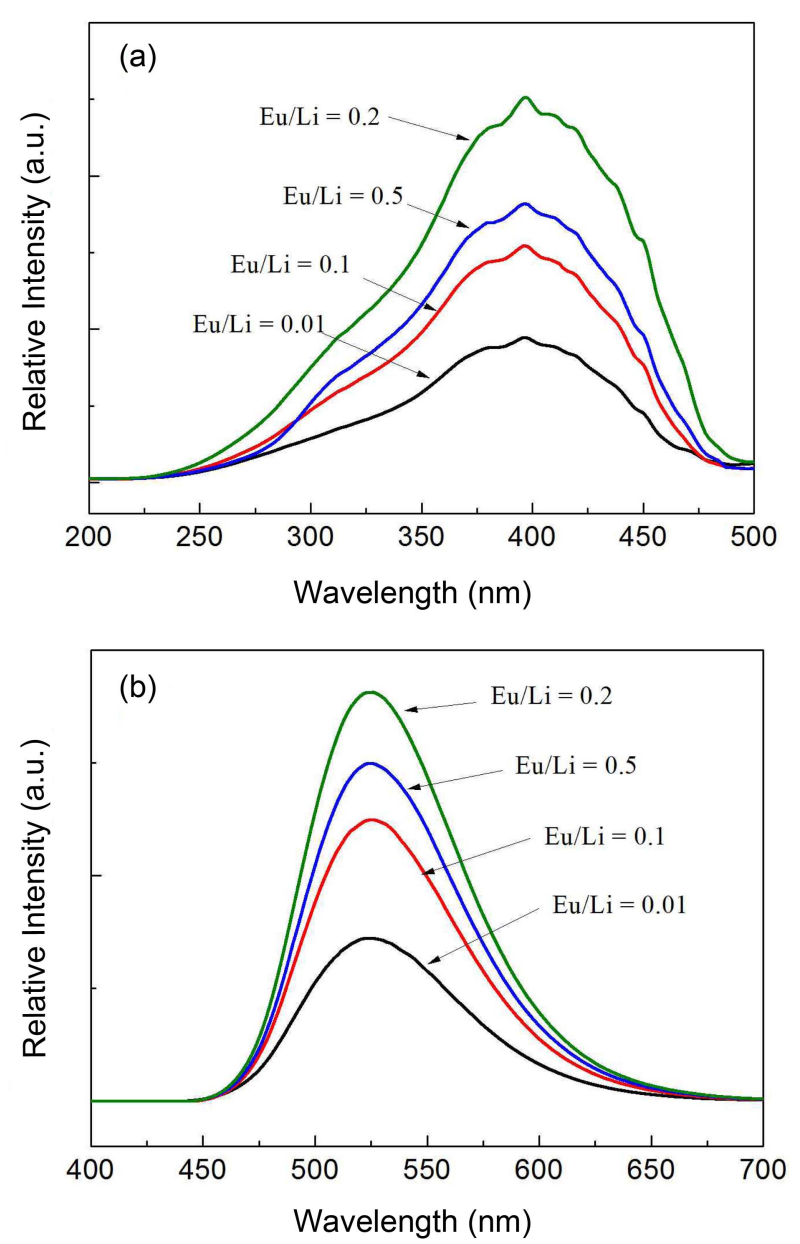

Fig. 3. PL spectrum of Eu-doped $\gamma-\mathrm{LiAlO}_{2}(\mathrm{Eu} / \mathrm{Li}=0.01,0.1$, $0.2,0.5)$. The samples were annealed at $1100^{\circ} \mathrm{C}$ in air for $5 \mathrm{~h}$ and then reduced under vacuum with 1 torr $\mathrm{H}_{2}$ at $1100^{\circ} \mathrm{C}$ for $5 \mathrm{~h}:$ (a) the excitation spectrum measured while observing the emission line at $524 \mathrm{~nm}$ and (b) the emission spectrum measured under the $396 \mathrm{~nm}$ excitation.

서는 거의 발광을 하지 못하다가 (오른쪽 사진의 흰색 화 살표 표시) $254 \mathrm{~nm}$ 에서 밝은 적색 형광 특성을 보이는 것을 확인할 수 있다. 환원 열처리에 의해 녹색 형광체로 변화한 경우에는 Fig. 3의 여기-발광 스펙트럼에서 예측 할 수 있듯이 $254 \mathrm{~nm}$ 및 $365 \mathrm{~nm}$ 에서 모두 $\mathrm{Eu} / \mathrm{Li}=$ $0.01(\mathrm{RX} 0)$ 과 $\mathrm{Eu} / \mathrm{Li}=0.1(\mathrm{RX} 1)$ 의 조성보다는 $\mathrm{Eu} / \mathrm{Li}=$ $0.2(\mathrm{RX} 2)$ 에서 가장 밝은 발광강도를 보이는 것을 확인할 수 있으며, 이후 $\mathrm{Eu}$ 이온의 첨가량이 증가하면 $(\mathrm{Eu} / \mathrm{Li}=$ 0.5 (RX5)) 오히려 발광강도가 감소하는 것 (Fig. 3의 결과 와 일치)을 관찰할 수 있다. 이는 형광체에서 발광 센터 (activator) 이온의 농도가 일정값 이상으로 증가하면 발광 강도가 감소하는 전형적인 concentration quenching 현상으 로 이해된다. Fig. 5는 수소 환원 열처리 온도가 발광강 도값에 미치는 영향을 확인하고자 $\mathrm{Eu} / \mathrm{Li}=0.1$ 조성의 


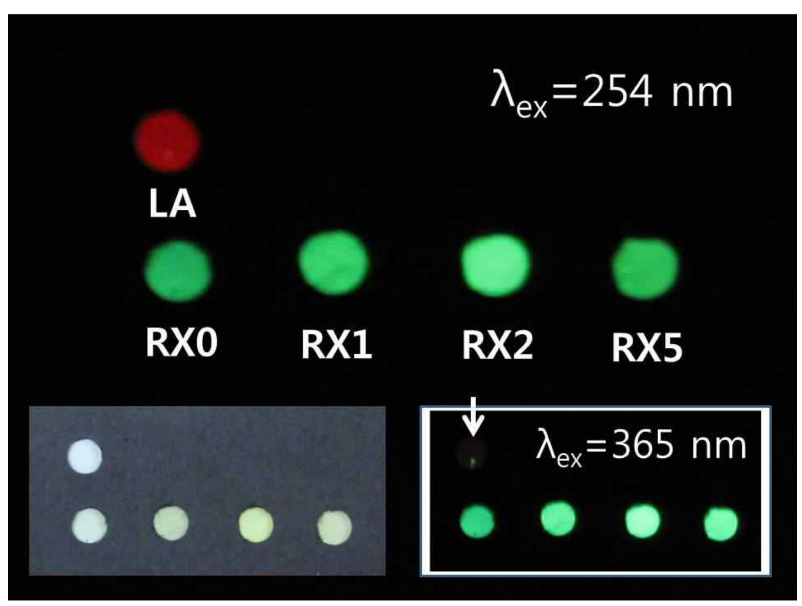

Fig. 4. Photographs of Eu doped $\gamma-\mathrm{LiAlO}_{2}$ samples under 254 (upper part) and $365 \mathrm{~nm}$ (inset on the lower right) UV light. Inset on the left shows a photograp $22 \mathrm{~h}$ of the same samples under natural light. LA indicates Eudoped $\gamma-\mathrm{LiAlO}_{2}(\mathrm{Eu} / \mathrm{Li}=0.1)$ annealed at $1100^{\circ} \mathrm{C}$ in air for $5 \mathrm{~h}$ and RX0 $\sim \mathrm{RX} 5$ indicates reduced samples $(\mathrm{Eu} / \mathrm{Li}=0.01,0.1,0.2,0.5)$ under vacuum with 1 torr $\mathrm{H}_{2}$ at $1100^{\circ} \mathrm{C}$ for $5 \mathrm{~h}$.

$\mathrm{LiAlO}_{2}$ 형광체 분말을 선택하여 1000,1100 , 그리고 $1200^{\circ} \mathrm{C}$ 에서 5 시간 환원 열처리하여 얻은 형광체의 발광 강도값의 변화이다. $1100^{\circ} \mathrm{C}$ 에서 열처리한 경우가 가장 우 수한 발광 강도값을 보이고 있어 환원 열처리 온도에 따 라 발광강도값이 영향을 받는 것을 알 수 있다.

한편, 수소 환원열처리에 의한 상변화를 관찰하기 위해 서 $\mathrm{LiAlO}_{2}: 0.1 \mathrm{Eu}$ 형광체에 대해 환원 열처리 전후의 $\mathrm{XRD}$ 분석결과를 Fig. 6에 나타내었다. Fig. 6(a)는 $\mathrm{Eu}$ 이 온을 첨가하지 않은 모체 $\mathrm{LiAlO}_{2}$ 만을 합성하여 관찰한 결과이며, (b)는 $\mathrm{Eu}$ 이온을 첨가하여 $1100^{\circ} \mathrm{C}$ 에서 5 시간 고상합성법으로 반응시켜 얻은 적색 형광체 $\mathrm{LiAlO}_{2}$ : $0.1 \mathrm{Eu}^{3+}$ 의 결과이다. Fig. 6 의 (c) (e)는 (b)의 적색 형광 체를 다시 $1000^{\circ} \mathrm{C}, 1100^{\circ} \mathrm{C}$, 그리고 $1200^{\circ} \mathrm{C}$ 에서 각각 수소 를 흘리며 1 torr의 분위기에서 5 시간 환원 열처리하여 녹 색형광체로 변화시킨 이후의 결과들이다.

우선, Fig. 6 (a)로부터 $1100^{\circ} \mathrm{C}$ 공기 중에서 합성한 $\mathrm{LiAlO}_{2}$ 는 정방정 (tetragonal)의 $\gamma-\mathrm{LiAlO}_{2}$ 상 (JCPDS 750905 , 정삼각형 스으로 표시)임을 확인할 수 있다. 여기에 $\mathrm{Eu}_{2} \mathrm{O}_{3}$ 를 첨가하여 공기 중에서 재합성한 $\mathrm{LiAlO}_{2}: 0.1 \mathrm{Eu}^{3+}(\mathrm{b})$ 는 입방정 $\mathrm{Eu}_{2} \mathrm{O}_{3}$ (JCPDS 86-2476, 정사각형 $\mathbf{\square}$ 으로 표시)와 정방정의 $\gamma-\mathrm{LiAlO}_{2}$ 상이 동시에 관찰되고 있다. 이는 첨가 된 $\mathrm{Eu}_{2} \mathrm{O}_{3}$ 가 완전히 고용되지 않고 일부 $\mathrm{Eu}_{2} \mathrm{O}_{3}$ 로 남아있 는 것을 의미한다.

한편 Fig. 6(c)는 Fig 6(b)의 적색 형광체를 $1000^{\circ} \mathrm{C}$ 에서 1 torr의 진공에서 수소를 흘리며 환원시킨 경우로 환원 전에는 관찰되지 않던 새로운 피크들이 관찰된다. 온도를

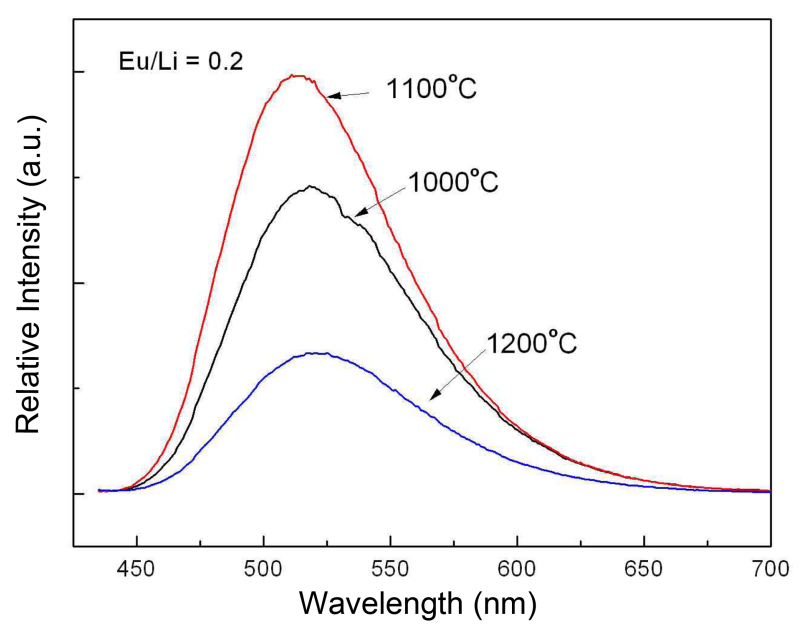

Fig. 5. Relative PL intensity of Eu-doped $\gamma-\mathrm{LiAlO}_{2}(\mathrm{Eu} / \mathrm{Li}=$ 0.1 ) according to reduction temperatures under vacuum with 1 torr $\mathrm{H}_{2}$ for $5 \mathrm{~h}$.

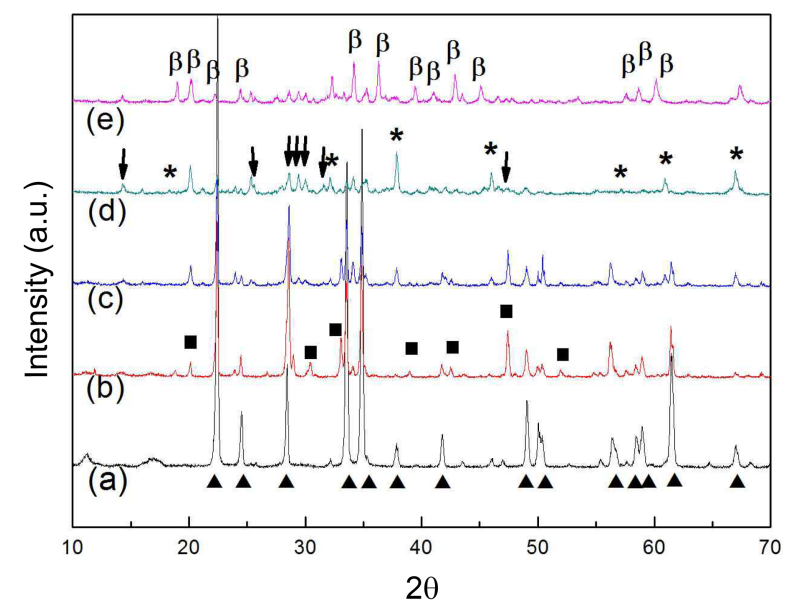

Fig. 6. XRD patterns of (a) $\gamma-\mathrm{LiAlO}_{2}(\mathrm{Eu} / \mathrm{Li}=0.1)$ and (b) $\mathrm{Eu}-$ doped $\gamma-\mathrm{LiAlO}_{2}(\mathrm{Eu} / \mathrm{Li}=0.1)$ samples annealed at $1100^{\circ} \mathrm{C}$ in air for $5 \mathrm{~h}$. (c) $\sim$ (e) prepared by reduction of (b) sample under vacuum with 1 torr $\mathrm{H}_{2}$ at 1000,1100 , and $1200^{\circ} \mathrm{C}$ for $5 \mathrm{~h}$, respectively $\left(\boldsymbol{\Delta}: \gamma-\mathrm{LiAlO}_{2}, \mathbf{\square}\right.$ : cubic $\mathrm{Eu}_{2} \mathrm{O}_{3}, \boldsymbol{V}$ : monoclinic $\mathrm{Eu}_{2} \mathrm{O}_{3}, *: \mathrm{Li}_{2} \mathrm{Al}_{4} \mathrm{O}_{7}, \beta$ : $\beta-\mathrm{Al}_{2} \mathrm{O}_{3}$ ).

증가시켜 열처리 온도를 $1100^{\circ} \mathrm{C}$ 로 한 경우 (Fig. 6(d))에 는 새로운 피크의 강도가 더욱 증가하고 있는데, 이 새로 운 상은 소량의 단사정 (monoclinic) $\mathrm{Eu}_{2} \mathrm{O}_{3}$ (화살표로 표 시)과 $\mathrm{Li}_{2} \mathrm{Al}_{4} \mathrm{O}_{7}$ (JCPDS 87-1279, *로 표시)상으로 확인되었 다. 즉, 초기의 적색 형광체의 모체였던 $\gamma-\mathrm{LiAlO}_{2}$ 상은 $1100^{\circ} \mathrm{C}$ 에서의 환원 열처리에 의해 거의 사라지고, 새롭게 합성된 $\mathrm{Li}_{2} \mathrm{Al}_{4} \mathrm{O}_{7}$ 가 주된 상으로 관찰되고 있다. $1200^{\circ} \mathrm{C}$ 로 환원 열처리 온도를 더욱 증가시키는 경우 (Fig 6(e))에는 $1100^{\circ} \mathrm{C}$ 에서 주된 상이었던 $\mathrm{Li}_{2} \mathrm{Al}_{4} \mathrm{O}_{7}$ 상은 사라지고 $\beta-\mathrm{Al}_{2} \mathrm{O}_{3}$ ( $\beta$ 로 표시)상이 주된 상 (phase)으로 생성되는 것을 알 수 있다. 
Fig. 5와 Fig. 6의 결과로부터 진공의 수소 환원열처리 에 의해 Li-Al-O계에서의 녹색 형광 특성과 발광강도값 은 환원열처리에 의해 생성되는 $\mathrm{Li}_{2} \mathrm{Al}_{4} \mathrm{O}_{7}$ 상의 생성과 밀 접한 관계가 있는 것을 알 수 있다. 즉, 진공의 환원열처 리에 의해 초기의 주상인 $\gamma-\mathrm{LiAlO}_{2}$ 상이 $1000^{\circ} \mathrm{C}$ 에서 사라 지고 새로운 $\mathrm{Li}_{2} \mathrm{Al}_{4} \mathrm{O}_{7}$ 상이 관찰되면서 녹색 형광특성을 보이게 되며, 새로이 합성된 $\mathrm{Li}_{2} \mathrm{Al}_{4} \mathrm{O}_{7}$ 상이 주된 상으로 관 찰되는 $1100^{\circ} \mathrm{C}$ 에서 녹색의 최대 발광강도값을 보인다. 이 후 $1200^{\circ} \mathrm{C}$ 에서의 환원열처리에 의해 $\mathrm{Li}_{2} \mathrm{Al}_{4} \mathrm{O}_{7}$ 상의 피크 값이 약해지면 발광강도값이 감소하고 있다. $\mathrm{Li}_{2} \mathrm{Al}_{4} \mathrm{O}_{7}$ 상 은 $\mathrm{Li}_{2} \mathrm{O}-\mathrm{Al}_{2} \mathrm{O}_{3}$ 계에서 관찰되는 상 (phase)중의 하나로 알 려져 있다. ${ }^{9}$ 지금까지는 이 화합물에서는 $\mathrm{Eu}$ 이온의 첨 가에 의한 녹색 형광특성이 보고된 바는 없다. $\mathrm{Eu}_{2} \mathrm{O}_{3}$ 가 첨가된 $\gamma-\mathrm{LiAlO}_{2}$ 에서 수소를 이용한 진공 환원열처리에 의해 $\mathrm{Li}_{2} \mathrm{Al}_{4} \mathrm{O}_{7}$ 상이 형성되고, $\mathrm{Li}_{2} \mathrm{Al}_{4} \mathrm{O}_{7}$ 상에 의해 녹색 형 광체 특성과 발광강도 값이 변화하고 있다. $\gamma-\mathrm{LiAlO}_{2}: \mathrm{Eu}$ 계 형광체에서 환원 열처리에 의해 $\gamma-\mathrm{LiAlO}_{2}$ 상이 $\mathrm{Li}_{2} \mathrm{Al}_{4} \mathrm{O}_{7}$ 으로 변화하고, 열처리 온도가 증가하면서 다시 $\beta-\mathrm{Al}_{2} \mathrm{O}_{3}$ 상으로 변화하는 상변화 현상은 $\mathrm{Li}$ 원소의 증발에 기인 하는 것으로 여겨진다. 즉, 1 torr의 진공 환원분위기에서 $\mathrm{Li}$ 이온의 증발로 $\mathrm{Li}$ 이온 성분이 결핍된 상으로의 변화 가 진행된 것으로 생각된다.

Fig. 7(a)는 $\mathrm{Li}_{2} \mathrm{Al}_{4} \mathrm{O}_{7}$ 의 결정구조 $(\mathrm{SG} \mathrm{Fd}-3 \mathrm{~m}, \mathrm{a}=\mathrm{b}=$ $7.91 \AA)^{13)}$ 를 보여준다. 결정구조학적으로 이 조성은 $\left(\mathrm{Li}_{0.25} \mathrm{Al}_{0.75}\right)_{2}\left(\mathrm{Li}_{0.75} \mathrm{All}_{.25}\right)_{2} \mathrm{O}_{7}$ 으로 나타낼 수 있다. $\left(\mathrm{Li}_{0.25}\right.$ $\left.\mathrm{Al}_{0.75}\right)_{2}$ 와 $\left.\left(\mathrm{Li}_{0.75} \mathrm{Al1}{ }_{.25}\right)_{2} \mathrm{~A}\right)$ 를 각각 $\mathrm{A}, \mathrm{B}$ 자리로 한다면 $\mathrm{A}$ 자리는 4 면체 산소배위를 하고, $\mathrm{B}$ 자리는 8 면체 산소배위 를 한다. 4 면체 및 8 면체 산소배위에서 배위다면체의 체 적 및 양이온 $(\mathrm{A} / \mathrm{B})-\mathrm{O}^{2-}$ 결합거리는 각각 $2.90 \AA^{3} / 9.29 \AA^{3}$, $1.78 \AA / 1.94 \AA$ 이다. 배위다면체의 체적 (volume) 및 결합 거리로 볼 때 $\mathrm{Eu}^{2+}$ 이온은 8 면체 배위자리에 치환될 가 능성이 크다. Fig. 2(b)는 $\mathrm{Li}_{2} \mathrm{Al}_{4} \mathrm{O}_{7}$ 의 결정구조 내에 8 면체 격자간 자리 $\left(\begin{array}{lll}1 / 8 & 1 / 8 & 1 / 8\end{array}\right)$ 의 위치와 가상적 배위를 나타 낸다. 이 8 면체 배위 다면체의 체적은 $10.9 \AA^{3}$, 다면체 중 심에서 $\mathrm{O}^{2-}$ 이온 중심까지의 거리는 $2.0 \AA \AA$ 으로서 이 비 워진 격자간 자리도 $\mathrm{Eu}$ 이온의 부분적으로 차지할 가능 성이 있다.

$\mathrm{Li}_{2} \mathrm{Al}_{4} \mathrm{O}_{7}$ 는 스피넬구조에서 파생된 결정구조로, Fig. 7(a) 에 나타낸바와 같이 산소자리의 점유율 (occupancy)이 0.875 로, 산소이온이 부분적으로 채워진 defective 구조이 다. 따라서 형광체 내에 $\mathrm{Eu}$ 이온이 치환되는 과정에서 필 요한 charge balance나 또는 고온에서 환원처리하는 과정 에서 $\mathrm{Eu}^{3+}$ 가 $\mathrm{Eu}^{2}+$ 로 환원될 때 필요한 charge balance는 산소자리의 occupancy가 변화됨으로써 쉽게 만족시켜질 수 있다고 판단된다.

한편, Fig. 6의 XRD 데이터를 통해 수소 환원열처리에 의해 녹색형광 특성을 보이는 시편에서도 여전히 단사정

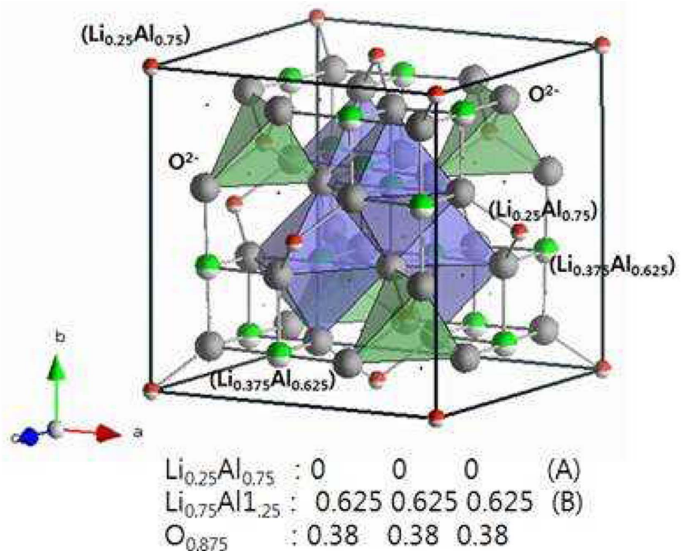

(a)

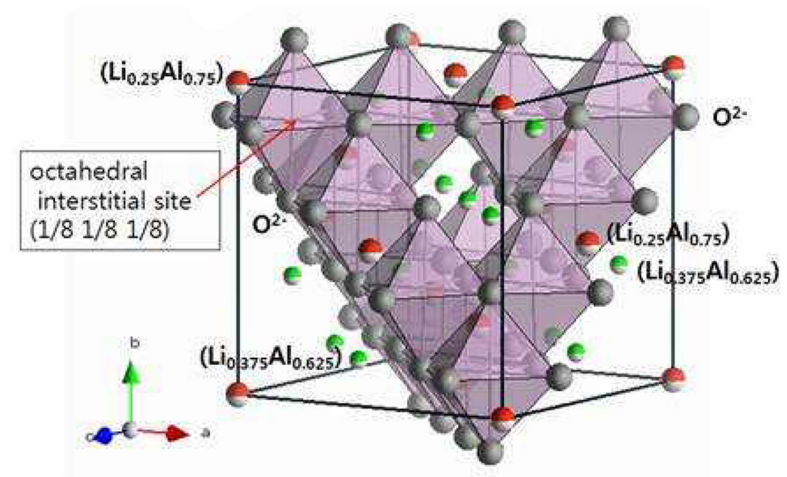

(b)

Fig. 7. Crystal structure of (a) the $\mathrm{Li}_{2} \mathrm{Al}_{4} \mathrm{O}_{7}$ and (b) octahedral interstitial sites.

의 $\mathrm{Eu}_{2} \mathrm{O}_{3}$ 상이 관찰되고 있다. 일반적으로 $\mathrm{Eu}_{2} \mathrm{O}_{3}$ 는 적색 형광특성을 보인다. 그러나 $\mathrm{Eu}_{2} \mathrm{O}_{3}$ 상은 진공 ( 10 torr)의 수소 환원열처리가 이루어지는 경우 $\mathrm{Eu}_{2} \mathrm{O}_{3}$ 자체의 발광 (적색) 특성은 거의 사라지는 것으로 보고된 바 있다. ${ }^{14)}$ 따라서 Fig. 6의 $\mathrm{XRD}$ 에서 관찰되는 $\mathrm{Eu}_{2} \mathrm{O}_{3}$ 상은, 일부는 팔면체 격자공간에 침입하고 나머지 $\mathrm{Li}-\mathrm{Al}-\mathrm{O}$ 계에 포함되 지는 못한 것으로, 수소 환원열처리가 이루어진 $\mathrm{Li}_{2} \mathrm{Al}_{4} \mathrm{O}_{7}$ : $\mathrm{Eu}$ 계에서는 형광특성에는 어떠한 영향도 미치지 못할 것 으로 판단되며, 따라서 새롭게 형성된 $\mathrm{Li}_{2} \mathrm{Al}_{4} \mathrm{O}_{7}$ 상에 의해 녹색형광 특성이 구현되는 것으로 여겨진다.

Fig. 8은 Fig. 6에서 분석한 각각의 형광체 분말을 주사 전자현미경으로 관찰한 미세조직사진들이다. Fig 8(a)는 Fig. 6(b) 형광체를, Fig. 8의 (b) (d)는 각각 Fig. 6의 (c) (e) 형광체 분말의 미세조직이다. Fig. 8(a)의 환원열처리 전의 미세조직에서는 뚜렷하게 두 개의 상이 관찰되는 것 을 알 수 있다. $\mathrm{EDX}$ 분석과 Fig. 6의 결과로 부터 2 $4 \mu \mathrm{m}$ 의 크기로 관찰되는 작은 크기의 밝은 입자들은 $\mathrm{Eu}_{2} \mathrm{O}_{3}$ 이었으며, 이러한 작은 입자들을 포함하고 있는 기지상 입자는 $\gamma-\mathrm{LiAlO}_{2}$ 로 판단되었다. $\gamma-\mathrm{LiAlO}_{2}$ 의 경우 $20 \sim$ 

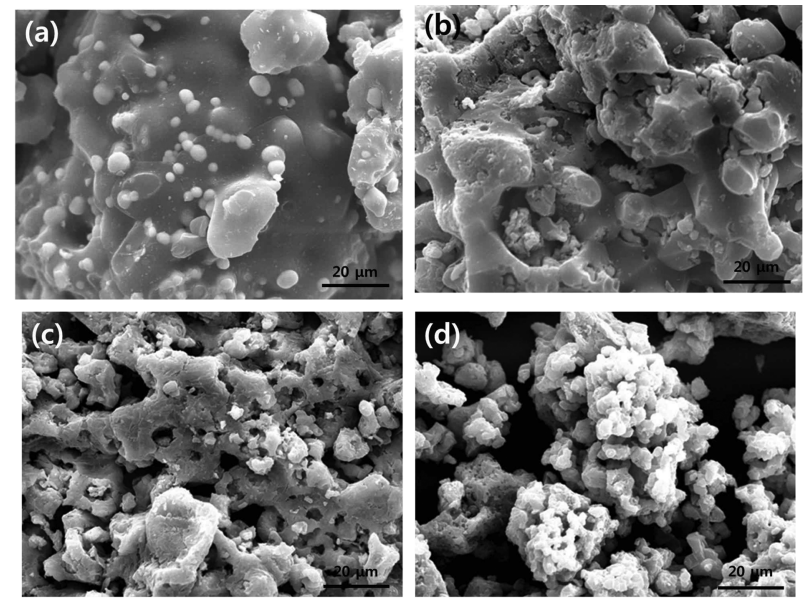

Fig. 8. SEM images for Eu-doped $\gamma-\mathrm{LiAlO}_{2}(\mathrm{Eu} / \mathrm{Li}=0.1)$ annealed at $1100^{\circ} \mathrm{C}$ in air for $5 \mathrm{~h}$ (a) and then reduced under vacuum with 1 torr $\mathrm{H}_{2}$ at 1000,1100 , and $1200^{\circ} \mathrm{C}$ for $5 \mathrm{~h}$, respectively ((b) $\left.\sim(\mathrm{d})\right)$.

$60 \mu \mathrm{m}$ 의 불규칙한 크기로 합성된 것은 원료분말로 첨가 된 낮은 녹는점 $\left(723^{\circ} \mathrm{C}\right)$ 의 $\mathrm{Li}_{2} \mathrm{CO}_{3}$ 에 의해 열처리 중 액상 소결과 같은 반응이 진행되었기 때문으로 생각된다. 한편 이렇게 합성된 $\gamma-\mathrm{LiAlO}_{2}$ 를 수소의 진공 환원분위기에서 열처리하는 경우 Fig. $8(\mathrm{~b}) \sim(\mathrm{d})$ 와 같은 미세조직의 변화 가 얻어진다. 우선 환원 열처리 온도가 증가함에 따라 합 성된 분말의 입자크기가 감소하고 있다. Fig. 8(d)에서 $1200^{\circ} \mathrm{C}$ 에서 환원시키는 경우 모든 입자가 $2 \mu \mathrm{m}$ 정도로 모두 작아진 것을 알 수 있다. Fig. 6의 XRD 결과로부터 환원 열처리에 의해 $\mathrm{Li}_{2} \mathrm{Al}_{4} \mathrm{O}_{7}$ 의 새로운 상이 생성되고 최 종적으로는 $\beta-\mathrm{Al}_{2} \mathrm{O}_{3}$ 상이 생성되는 것은 환원열처리 전의 $\gamma-\mathrm{LiAlO}_{2}$ 의 상분해를 통해 이루어지는 것으로 판단된다. 즉, 녹는점이 낮고 증기압이 높은 $\mathrm{Li}$ 이온이 1 torr의 진공 분위기에서 휘발하여 이루어지는 것으로 여겨진다. 환원 열처리 온도가 증가할수록 $\mathrm{Li}$ 이온의 휘발이 활발히 진 행되어 $\mathrm{Li}$ 이온이 적은 $\mathrm{Li}_{2} \mathrm{Al}_{4} \mathrm{O}_{7}$ 상이 형성되었다가 이후 더 높은 열처리온도에서 더 많은 $\mathrm{Li}$ 이온의 휘발로 $\beta$ $\mathrm{Al}_{2} \mathrm{O}_{3}$ 상으로 변화하는 것으로 판단된다.

\section{4. 결 론}

고상합성법을 통해 $\mathrm{Eu}_{2} \mathrm{O}_{3}$ 가 첨가된 $\gamma-\mathrm{LiAlO}_{2}$ 의 적색형 광체를 합성하였고, 이렇게 제조된 적색형광체를 수소를 이용한 진공 환원열처리를 통해 새로운 녹색 형광체를 얻 을 수 있었다. 고상합성법으로 합성된 $\gamma-\mathrm{LiAlO}_{2}: \mathrm{Eu}^{+3}$ 는 $283 \mathrm{~nm}$ 에서 최대 여기파장을 보였으며, 최대 발광파장은 $614 \mathrm{~nm}$ 로 전형적인 적색 형광체 특성을 보여 주었다. 그 러나 이후 수소를 이용하여 1 torr의 진공 환원 분위기에 서 열처리 하는 것에 의해 $396 \mathrm{~nm}$ 에서 최대 흡수피크를 보이며 $250 \sim 480 \mathrm{~nm}$ 의 넓은 영역에서 완만한 형태의 흡
수 파장이 관찰되었고, 발광스펙트럼은 $460 \sim 650 \mathrm{~nm}$ 의 넓 은 곡선을 이루며 $524 \mathrm{~nm}$ 으로 최대 발광피크를 보이는 전형적인 녹색형광체로 변화하였다.

$\gamma-\mathrm{LiAlO}_{2}: 0.1 \mathrm{Eu}^{+3}$ 를 진공 환원 열처리하는 경우 $1000^{\circ} \mathrm{C}$ 에서 $1100^{\circ} \mathrm{C}$ 로 열처리 온도가 증가할수록 $\mathrm{PL}$ 강도값은 증가하였고 $\gamma-\mathrm{LiAlO}_{2}$ 상은 $\mathrm{Li}_{2} \mathrm{Al}_{4} \mathrm{O}_{7}$ 상으로 변화하였다, 그 러나 열처리 온도를 더욱 증가시켜 $1200^{\circ} \mathrm{C}$ 에서 열처리하 는 경우 대부분이 $\beta-\mathrm{Al}_{2} \mathrm{O}_{3}$ 상으로 변화하면서, 발광 강도 값도 급격히 감소하였다. 이는 진공 환원 열처리에 의해 녹는점이 낮은 $\mathrm{Li}$ 이온의 휘발에 의한 상변화로 판단되 며, 미세조직의 관찰에서도 열처리 온도가 증가할수록 입 자크기가 감소하는 것을 확인할 수 있었다. $\mathrm{Eu}$ 이온이 +3 에서 +2 로 환원되면서 녹색형광체 특성을 보였으며, $\mathrm{Li}$ 이온의 휘발에 기인한 $\mathrm{Li}_{2} \mathrm{Al}_{4} \mathrm{O}_{7}$ 상의 생성이 발광강도값을 대폭 항상 시켰다.

\section{Acknowledgment}

본 논문은 2012년도 호서대학교의 재원으로 학술연구 비 지원 (2012-0279)을 받아 수행된 연구임.

\section{REFERENCES}

1. C. R. Ronda, T. Justel, and H. Nikol, "Rare Earth Phosphors: Fundamentals and Applications," J. Alloys Comp., 275-277 669-76 (1998).

2. W. M. Yen, S. Shionoya, and H. Yamamoto, Phosphor Handbook, Second Edition, pp. 204-207, CRC Press, 2006.

3. K. W. Chae, C. I. Cheon, and J. S. Kim, "Photoluminescence of $\mathrm{Al}_{2} \mathrm{O}_{3}: \mathrm{xCr}_{2} \mathrm{O}_{3}$ Solid Solution and Application as the Additive for Improving CRI of Red Phosphor," J. Kor Ceram. Soc., 47 [2] 122-26 (2010).

4. K. W. Chae, T. R. Park, C. I. Cheon, N. I. Cho, and J. S. $\mathrm{Kim}$, "The Enhancement of Luminescence in Co-doped Cubic $\mathrm{Eu}_{2} \mathrm{O}_{3}$ Using $\mathrm{Li}^{+}$and $\mathrm{Al}^{3+}$ Ions," J. Lumin., 131 [12] 2597-605 (2011).

5. C. H. Lu, H. C. Hong, and R. Jagannathan, "Sol-gel Synthesis and Photoluminescence Properties of Cerium-ion Doped Yttrium Aluminium Garnet Powders," J. Mater. Chem., 12 2525-30 (2002).

6. X. Yang, G. Ning, X. Li, and Y. Lin, "Synthesis and Luminescence Properties of a Novel $\mathrm{Eu}^{3+}$ Doped $\gamma-\mathrm{LiAlO}_{2}$ Phosphor," Mater. Lett., 61 [25] 4694-96 (2007).

7. F. Wang, X. Fan, D. Pi, Z. Wang, and M. Wang, "Hydrothermal Synthesis and Luminescence Behavior of Rareearth-doped $\mathrm{NaLa}\left(\mathrm{WO}_{4}\right)_{2}$ Powders," J. Solid State Chem., 178 [3] 825-30 (2005).

8. N. Suriyamurthy, B. S. Panigrahi, and A. Natarajan, "Luminescence Study of Iron Doped Lithium Aluminate Phosphor," Mater. Sci. Eng., A, 403 [1-2] 182-85 (2005).

9. M. A. Kale, C. P. Joshi, and S. V. Moharil, "Combustion Synthesis of Some Compounds in the $\mathrm{Li}_{2} \mathrm{O}-\mathrm{Al}_{2} \mathrm{O}_{3}$ System," 
Int. J. Self-Propag. High-Temp. Synth., 21 [1] 19-24 (2012).

10. K. W. Chae, T. R. Park, C. I. Cheon, N. I. Cho, and J. S. Kim, "Enhanced Phase Miscibility and Luminescence by Inducing Oxygen Vacancies in $\mathrm{Ce}_{1-\mathrm{x}} \mathrm{Eu}_{\mathrm{x}} \mathrm{O}_{2-\delta}$ under a Strongly Reducing Atmosphere," J. Lumin., 136 109-16 (2013).

11. J. Becerril, P. Bosch, and S. Bulbulian, "Synthesis and Characterization of $\gamma-\mathrm{LiAlO}_{2}$," J. Nucl. Mater., 185 [3] 304-07 (1991).

12. U. Hommerich, Y. Shen, and K. Bray, "High Pressure Luminescence Studies of $\mathrm{Cr}^{4+}$ Doped Laser Materials," J. Lumin.,
72-74 139-140 (1997).

13. M. Kriens, G. Adiwidjaja, W. Guse, K. H. Klaska, C. Lathe, and $\mathrm{H}$. Saalfeld, "The Crystal-structures of $\mathrm{LiAl}_{5} \mathrm{O}_{8}$ and $\mathrm{Li}_{2} \mathrm{Al}_{4} \mathrm{O}_{7}$, , Neues Jahrb. Mineral. Monatsh., 8 344-50 (1996).

14. K. W. Chae, T. R. Park, C. I. Chen, N. I. Cho, and J. S. Kim, "Luminescence Enhancement by the Reduction-oxidation Synthesis in Monoclinic $\mathrm{RE}_{2} \mathrm{O}_{3}(\mathrm{RE}=\mathrm{Eu}, \mathrm{Gd})$ Phosphors Containing $\mathrm{Eu}^{+3}$ Activator," J. Lumin., 132 2293-301 (2012). 